\title{
EXPRESSION PATTERNS OF THE HUMAN RIBOSOMAL PROTEIN GENES $e$ L14 AND $u S 19$ IN COLON CANCER IS DEPENDENT ON THE TYPE AND STAGE OF THE CANCER CELL
}

\author{
EDMUND UI-HANG SIM*, SELVAMALAR MUTSAMY and ZY-YING TEH \\ Faculty of Resource Science and Technology, Universiti Malaysia Sarawak, \\ 94300 Kota Samarahan, Sarawak, Malaysia \\ *E-mail: uhsim@unimas.my
}

Accepted 3 February 2020, Published online 30 June 2020

\begin{abstract}
Although the association of some ribosomal protein genes with colorectal cancer is widely known, the detailed mechanisms and complete list of associated genes is lacking. More importantly, the behaviours of these genes in different types and stages of the cancer are poorly understood. Herein we report the study of two ribosomal protein genes in cell lines derived from different sites and stages of colon cancer. Specifically, we analysed the expression pattern of eL14 and uS19 in HCT116 and SW480 cell lines. These two genes, although associated with a wide variety of cancer types, are poorly or have not been studied in colorectal cancer. Semi-quantitative reverse transcription - polymerase chain reaction (RT-PCR) approach was used, together with Students' $t$-test validation. We found a significantly $(p<0.05)$ differential $e L 14$ and $u S 19$ expression patterns between HCT116 and SW480 cell lines. Our findings suggest that eL14 and $u S 19$ have higher activity in a poorly differentiated cell line derived from advanced (metastatic) stage (Duke's Stage D) colorectal carcinoma tissues compared to the moderately differentiated cell line derived from a mid-stage (Duke's Stage B) colorectal adenocarcinoma tumour. This will have important implications for both ribosomal protein genes as type and stage specific biomarkers for colon cancer.
\end{abstract}

Key words: Ribosomal protein genes, colon cancer, transcript level, eL14, uS19

\section{INTRODUCTION}

Differential expression of ribosomal protein (RP) genes is widely reported in a variety of cancer types. Over the years, there is increasing evidence of their association with colorectal cancer (Pogue-Geile et al., 1991; Kondoh et al., 1992; Wang et al., 2000; Shenoy et al., 2012; Yu et al., 2019). Patterns of their expression also varies with different stages of malignancy (Lai \& Xu, 2007), thus substantiating their involvement in the carcinogenesis of colon cancer. While some RP genes have elevated expression in colorectal cancer (CRC), several others are down-regulated, particularly in metastatic CRC (Lai \& Xu, 2007). These RP genes are suspected to have specific roles in tumour progression and cancer metastasis, and cellular differentiation in CRC (Gou et al., 2010). However, not enough is known about the whole list of RP genes that is associated with

* To whom correspondence should be addressed.
CRC. Current literature lists at least 80 members of the RP gene family in existence (Ban et al., 2014). Exactly how many and which of these are linked to colorectal cancer is yet to be clarified. At what stages of the cancer are they most active also remains to be fully elucidated.

We sought to study the ribosomal protein gene L14 (eL14) in the context of colorectal carcinoma because its link to the different stages of malignancy of the cancer has never been properly studied. eL14 is located at a chromosomal position 3p21.3 (Huang et al., 2006) - a region where the loss of heterozygosity $(\mathrm{LOH})$ is associated with several types of cancer, and possibly have tumour suppressor genes (Liu et al., 2003). eL14 has been found to be differentially expressed in lung, oral, (Shriver et al., 1998), oesophageal (Huang et al., 2006), and nasopharyngeal (Sim et al., 2018) cancers. More importantly, it is strongly correlated to microsatellite instability in CRC cases ( $\mathrm{Yu}$ et al., 2019). In the case of RP gene S15 (uS19), despite 
an association with CRC (Lai \& Xu, 2007), nothing is known about its activity in the different types and stages of the cancer. Besides colon cancer, $u S 19$ is highly expressed in esophageal cancer and neuroblastomas (Walter et al., 1996), hepatocellular carcinoma (Yoon et al., 2006), and nasopharyngeal carcinoma (Fang et al., 2008; Sim et al., 2018). The uS19 protein is differentially expressed in human gastric carcinoma cells (Mao et al., 2016). Its mutations have been implicated in chronic lymphocytic leukemia (Ljungstrom et al., 2016; Sulima et al., 2017; Bretones et al., 2018; Ljungstrom \& Rosenquist, 2018). It is possibly associated with the modulation of the p53 tumour suppressor function via the MDM-2-p53 pathway (Daftuar et al., 2013). This has made it an interesting RP genes to be included in our study.

The two CRC cell lines (HCT116 and SW480) employed in our study were derived from different cell types and stages of the cancer. This suited our purpose of investigating the activities of eL14 and uS19 in different types and stages of CRC. HCT116 is a growth factor independent epithelial cell line (Rajput et al., 2008) derived from the Duke's Stage D (metastatic) cells of the ascending colon of a 48 years old male diagnosed with colorectal carcinoma (Niu et al., 2012). It is of tumour Grade IV and comprising poorly differentiated cells (Niu et al., 2012) that are largely cancer stem cells (Yeung et al., 2010). In contrast to HCT116, the SW480 cell line originated from tumour tissues of the descending colon a 50 years old male with Duke's Stage B (non-metastatic) colorectal adenocarcinoma (Flatmark et al., 2004). It is of tumour Grade III, consisting of moderately differentiated epitheliallike cells that have glandular characteristics (Romano et al., 2009; Niu et al., 2012).

This paper reports the expression behaviours at the transcript level of eL14 and $u S 19$ in HCT116 and SW480 cell lines with the aim of identifying and/or establishing association of these RP genes in $\mathrm{CRC}$, and to unravel their activities in different types and stages of the cancer.

\section{MATERIALS AND METHODS}

\section{Cell lines and culture}

The colorectal cell lines used for this study are HCT116 and SW480. Both cell lines were purchased from American Type Cell Culture (ATCC). HCT116 was derived from cells of the ascending colon of a 48 years old man with CRC. SW480 cell lines originated from the descending colon of a 50 years old man with colorectal adenocarcinoma. HCT116 were cultured in McCoy 5A media supplemented with 10\% Foetal Bovine Serum (FBS). Culture conditions were at $37^{\circ} \mathrm{C}$ with $5 \% \mathrm{CO}_{2}$, and $5 \%$ humidity. SW480 were cultured in L15 media supplemented with $10 \%$ FBS. Culture conditions were at $37^{\circ} \mathrm{C}$ with $5 \%$ humidity. Cells were harvested for total RNA extraction when they reached 70$80 \%$ growth confluence.

\section{Total RNA extraction}

Total RNA was extracted using the TRIzol method (Chomczynski \& Sacchi, 1987). Prior to the addition of TRIzol reagent (Invitrogen ${ }^{\mathrm{TM}}$, USA), cells were washed in cold phosphate buffer saline (PBS) solution. Suspension mixture in T25 culture flasks was transferred to $1.5 \mathrm{ml}$ sterile tubes, mixed by gentle pipetting, and left at room temperature (RT) for 5 minutes. Chloroform ( $1 / 5 \mathrm{vol}$.) was then added, and the lysate was briefing vortexed and left at RT for 2 minutes. This was centrifuged at 12,000 rpm for 15 minutes at $4{ }^{\circ} \mathrm{C}$. Then, the aqueous phase was transferred into a new $1.5 \mathrm{ml}$ tube, added with $0.5 \mathrm{ml}$ isopropanol and left at RT for 10 minutes. Centrifugation at $10,000 \mathrm{rpm}$ and $4{ }^{\circ} \mathrm{C}$ for 10 minutes followed. Then the supernatant was carefully removed leaving the RNA pellet, which was washed with $1 \mathrm{~mL}$ of $75 \%$ ethanol, and air dried for 5 minutes. It was then dissolved in nuclease-free water stored at $-80^{\circ} \mathrm{C}$ until use. Quantity and quality assessments were via agarose gel electrophoresis and UV spectrophotometry assays.

\section{Reverse Transcription - Polymerase Chain Reaction (RT-PCR) assay \\ Conversion of RNA to cDNA was carried} using Moloney Murine Leukemia Virus Reverse Transcriptase (MMLV-RT) (Promega, USA). RNA samples were mixed with random primers in a sterile $1.5 \mathrm{~mL}$ tube, and incubated at $70^{\circ} \mathrm{C}$ for 5 minutes. Following that, the mixture was immediately cooled on ice for 1 minutes, vortexed, and added with $1 \mathrm{X}$ M- MLV reaction buffer, $1 \mathrm{mM}$ dNTPs, Recombinant RNAsin ${ }^{\circledR}$ Ribonuclease Inhibitor, and $1 \mathrm{U}$ of M- MLV RT. This was incubated at $37^{\circ} \mathrm{C}$ for 60 minutes, and then at $70^{\circ} \mathrm{C}$ for 15 minutes. Enzymatic amplification of eL14 and $\mathrm{uS} 19$ via PCR was according to the following conditions and parameters. Each reaction comprised 1X Green GoTaq ${ }^{\circledR}$ Flexi Buffer, $1 \mathrm{mM} \mathrm{MgCl}$, $0.2 \mathrm{mM}$ dNTP Mix, $0.4 \mu \mathrm{M}$ forward primer, $0.4 \mu \mathrm{M}$ reverse primer, and $0.6 \mathrm{U}$ GoTaq ${ }^{\circledR}$ Polymerase, and $0.5 \mu \mathrm{g}$ template DNA. Negative control contained no template DNA in the reaction mix. PCR test using $G A P D H$ was used as a control for monitoring comparable amount use of template DNA. The PCR primers used in our study include the forward and reverse primers of $e L 14$ (5'-ATGGTGTTCAGGCG CTTC G-3'; 5'-CCACTGTCAAGCTGCCTCC-3'), uS19 (5'-GAAGACGCACCTGCGGGACA-3'; 5'GTGGCCGATCATCTCGGGCTTG-3'), and GAPDH (5'-AGATCATCAGCAATGCCTC-3'; 5'-TACC 
AGGACATGAGCTTGAC-3’). Expected amplicon sizes for the primer pairs are $760 \mathrm{bp}(e L 14), 115 \mathrm{bp}$ (uS19), and 508 bp (GAPDH). The thermal cycling parameters of PCR assay for each gene were as follows: For $e L 14,30$ cycles of denaturation at $95^{\circ} \mathrm{C}$ for 0.5 minutes, annealing at $57^{\circ} \mathrm{C}$ for 0.5 minutes, and extension at $72^{\circ} \mathrm{C}$ for 1 minutes; for $u S 19$, eL14, 30 cycles of denaturation at $95^{\circ} \mathrm{C}$ for 0.5 minutes, annealing at $57.6^{\circ} \mathrm{C}$ for 0.5 minutes, and extension at $72^{\circ} \mathrm{C}$ for 1 minutes; and for GAPDH, 30 cycles of denaturation at $95^{\circ} \mathrm{C}$ for 0.5 minutes, annealing at $50.7^{\circ} \mathrm{C}$ for 0.5 minutes, and extension at $72^{\circ} \mathrm{C}$ for 1 minutes. Assessment of PCR assays was via agarose gel electrophoresis (AGE), and band intensities of amplified products were documented and quantified using ImageQuant Imager and associated software (GE Healthcare Life Sciences, USA). Amplicons were also verified by sequence analysis.

\section{DNA analysis}

Expression patterns of each gene were measured based on band intensities of RT-PCR products observed on AGE assay. Biological replicates (duplicates) were implemented in this study. Data normalization was done by comparing values of RP genes with the housekeeping gene, GAPDH. Differential expression of RP genes between the two cell lines was evaluated using paired Student's $t$ test, with significance taken at $p$-value $<0.05$.

\section{RESULTS AND DISCUSSION}

\section{eL14 expression pattern in colon cancer cell lines}

The eL14 expression as detected in the colorectal carcinoma cell line (HCT116) but not in the colorectal carcinoma cell line (SW480). Electrophoretic results of this observation (Figure 1(A)) were substantiated by band intensity assessment (Table 1), and illustrated in a bar chart (Figure 1(B)). Sequence analysis verified the authenticity of the amplicon, as bone fide PCRamplified products of the $e L 14$ gene ( $85 \%$ identical with reference data in GenBank, Fig. 3(A)). Amplicons of the housekeeping gene (as internal control), GAPDH was also sequence verified (96\% identical with reference data in GenBank, Fig. 3(C)). It is clear that the expressed transcript level between the two cell lines is significantly different even without inferential statistical evaluation. Despite the fact that high band intensity value (mean normalized value of $36150.90 \pm 967.19$ ) was evident in HCT116 cell lines, no detectable expression (band intensity value of 0.00) was observed in SW480 cells (Figure 1, Table 1).

The obvious expression deficiency in SW480 is not an unexpected result, albeit proven for the first time in a colon cancer model in this study. Early and circumstantial evidence of eL14 inactivation in cancer was from observation of frequent loss of heterozygosity at chromosomal region 3 p21.3 in squamous cell carcinoma of the head and neck (SCCHN) (Shriver et al., 1998). The eL14 gene resides within this region. The cause of eL14 loss and/or inactivation in cancers is still unknown. Interestingly, our study unveiled expression of eL14 in HCT116 cell line. This provides evidence that $e L 14$ is not necessary inactivated or down-regulated in cancer cells, thus adding to the complexity of its involvement in cancer, particularly colon cancer. This difference in expression could be partly attributed by disparity in cell types between HCT 116 and SW480. Both originated from different sites of the colorectal organ (HCT116 and SW480 from ascending and descending colon respectively), composed of dissimilar degree of cellular differentiation (HCT116 is poorly differentiated whereas SW480 is moderately differentiated epithelial-like form with glandular characteristics), and were from different stages of malignancy (HCT116 is at Duke's Stage D metastatic status while SW480 is at Duke's Stage B non-metastatic status). Alteration of gene expression in relation to different stages of CRC is a phenomenon that has been previously reported (Kawada et al., 2003; Lai $\& \mathrm{Xu}, 2007)$. Nevertheless, how these cellular and pathologic differences contribute to the behavioural disparities of eL14 observed in our study remains to be experimentally explored.

uS19 expression pattern in colon cancer cell lines

Our analysis revealed detectable expression of uS19 in both HCT116 and SW480 cell lines (Figure 2(A), Table 2). Sequence analysis verified the authenticity of the amplicon, as bone fide PCR-amplified products of the $u S 19$ gene $(100 \%$ identical with reference data in GenBank, Figure 3(B)). Expression in HCT116 was markedly higher compared to SW480 (Figure 2(B), Table 3). Comparison of mean normalized value of the band intensity for the $u S 19$ gene amplicons between HCT116 and SW280 revealed of 1.576-fold difference. This difference is significant with $p$-value of 0.026 following Student's $t$-test analysis.

In contrast to the behavior of eL14, expression uS19 was detected in both HCT116 and SW480. We have also demonstrated that the level of $u S 19$ was higher in HCT116 than SW480. Unlike eL14, association of $u S 19$ with colon cancer has been previously reported (Lai \& $\mathrm{Xu}, 2007)$. However, this paper is the first to show evidence of its significantly varied expression between colon cancer cells of different types and stages. $u S 19$ is highly expressed in poorly differentiated, metastatic CRC cells. Further functional studies on regulatory network of 


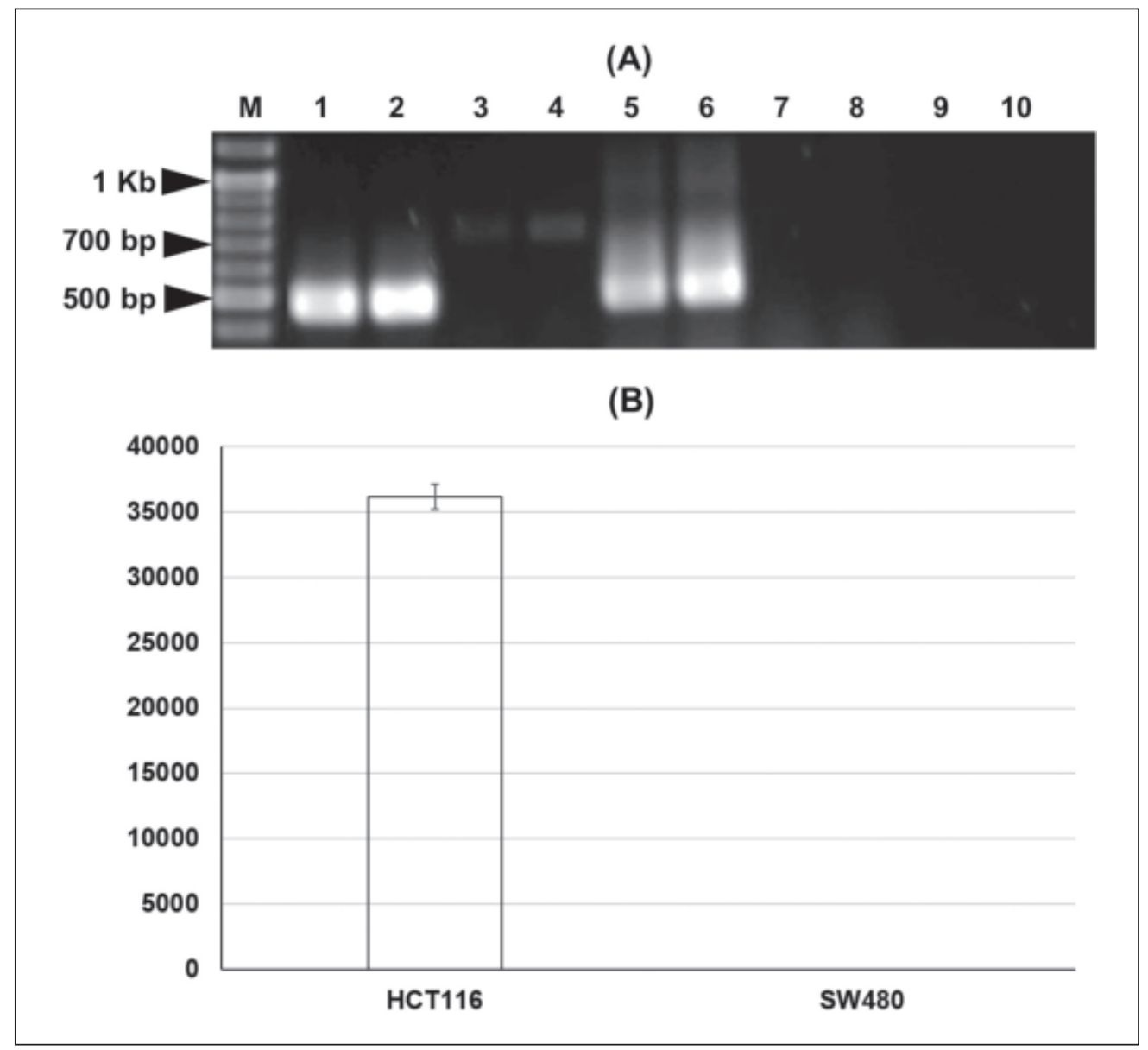

Fig. 1. Expression pattern of $e L 14$ in HCT116 and SW480 cell lines. (A), Gel electrophoretic results of eL14 RT-PCR assay (lane M: GeneRuler ${ }^{\mathrm{TM}}$ DNA Ladder; lanes 1 and 2: GAPDH amplicons in HCT116; lanes 3 and 4: eL14 amplicons in HCT116; lanes 5 and 6: GAPDH amplicons in SW480; lanes 7 and 8: eL14 amplicons in SW480; and lanes 9 and 10 are negative controls of eL14 test for HCT116 and SW480 respectively). (B), Column chart of mean band intensity value with standard deviation error bar of eL14 amplicons in both colon cancer cell lines. The y-axis represents band intensity values, and the $\mathrm{x}$-axis is the type of cell lines.

Table 1. Band intensity value of $e L 14$ and GAPDH amplicons in HCT116 and SW480 cell lines

\begin{tabular}{lcccccr}
\hline \multirow{2}{*}{ Cell lines } & $\begin{array}{c}\text { Replicate } \\
\text { test }\end{array}$ & eL14 & GAPDH & $\begin{array}{c}\text { Normalized } \\
\text { eL14 }\end{array}$ & $\begin{array}{c}\text { Mean } \\
\text { normalized } e L 14\end{array}$ & $\begin{array}{r}\text { Standard } \\
\text { Deviation }\end{array}$ \\
\cline { 3 - 6 } HCT116 & 1 & 36321.33 & 165835.28 & 35474.77 & 36150.90 & 956.19 \\
& 2 & 38293.54 & 163290.25 & 36827.03 & & 0.00 \\
SW480 & 1 & 0.00 & 173787.09 & 0.00 & 0.00 & \\
& 2 & 0.00 & 176258.23 & 0.00 & & \\
\hline
\end{tabular}

uS19 in CRC carcinogenesis would be required to unravel the molecular rationale underlying this observation.

Our findings on eL14 and uS19 suggest a marked or elevated expression of these genes in metastatic rather non-metastatic colon cancer cells. Although differential expression of up to 18 RPs in tumour cell lines of the same origin but different metastatic abilities has been reported (Kreunin et al., 2007), our study is the first to demonstrate this for eL14 and $u S 19$ in colorectal malignancy. This implies biomarker of prognostic potential for these two RP genes in carcinogenesis of the colorectum. Nonetheless, further evaluation of their protein 


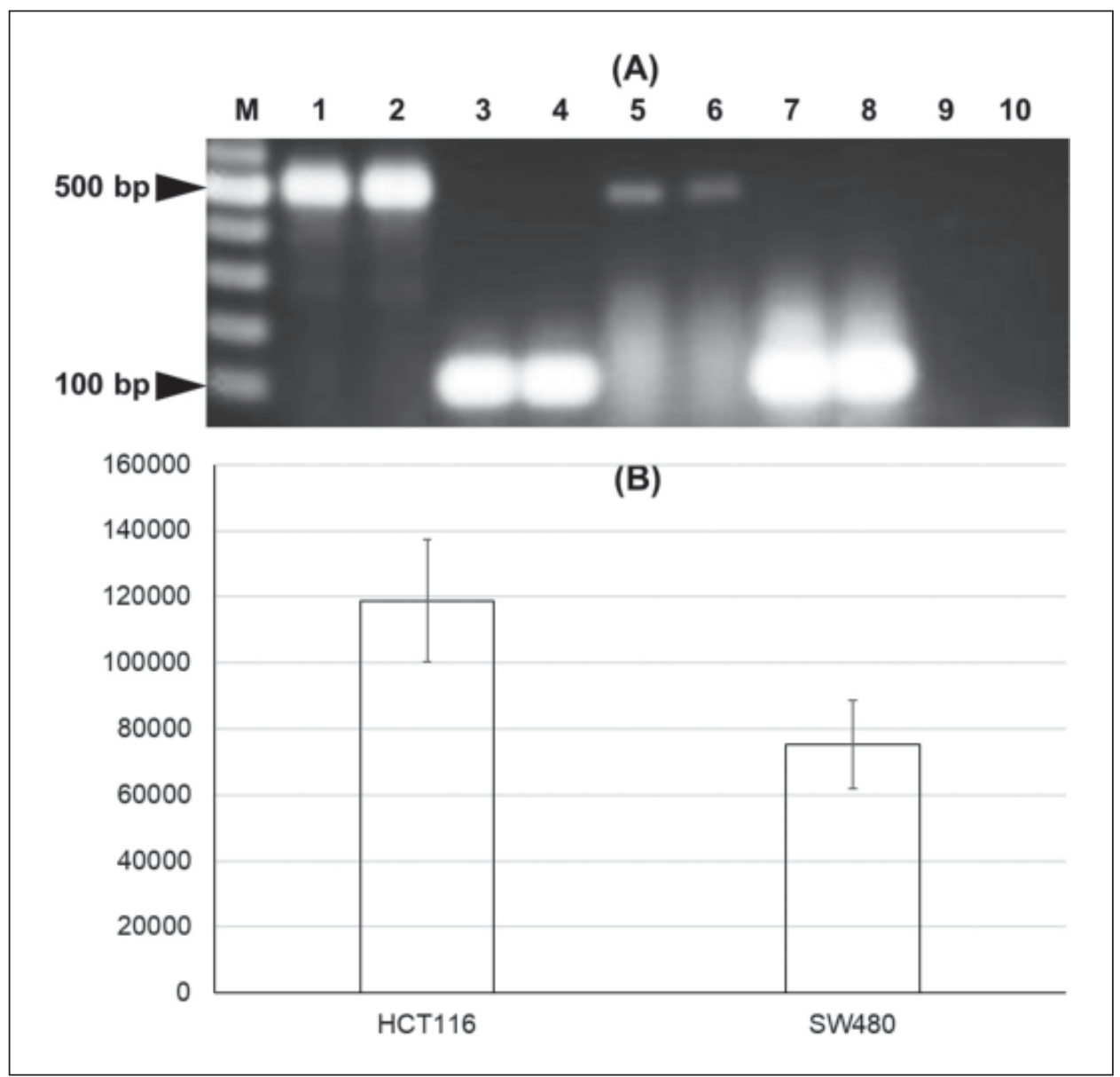

Fig. 2. Expression pattern of $u S 19$ in HCT116 and SW480 cell lines. (A), Gel electrophoretic results of $u S 19$ RT-PCR assay (lane M: GeneRuler ${ }^{\mathrm{TM}}$ DNA Ladder; lanes 1 and 2: GAPDH amplicons in SW480; lanes 3 and 4: $u S 19$ amplicons in SW480; lanes 5 and 6: GAPDH amplicons in HCT116; lanes 7 and 8: $u S 19$ amplicons in HCT116; and lanes 9 and 10 are negative controls of $u S 19$ test for HCT116 and SW480 respectively). (B), Column chart of mean band intensity value with standard deviation error bar of $u S 19$ amplicons in both colon cancer cell lines. The yaxis represents band intensity values, and the $\mathrm{x}$-axis is the types of cell line.

Table 2. Band intensity value of $U S 19$ and GAPDH amplicons in HCT116 and SW480 cell lines

\begin{tabular}{lcccccr}
\hline \multirow{2}{*}{ Cell lines } & $\begin{array}{c}\text { Replicate } \\
\text { test }\end{array}$ & uS19 & GAPDH & $\begin{array}{c}\text { Normalized } \\
\text { uS19 }\end{array}$ & $\begin{array}{c}\text { Mean } \\
\text { normalized uS19 }\end{array}$ & $\begin{array}{c}\text { Standard } \\
\text { Deviation }\end{array}$ \\
\cline { 3 - 6 } HCT116 & 1 & 120113.63 & 19152.49 & 105669.2522 & 118773.54 & 18532.23 \\
& 2 & 144055.89 & 19930.11 & 131877.8364 & & 13412.67 \\
SW480 & 1 & 62214.00 & 23019.64 & 65783.61721 & 75267.80 & \\
& 2 & 73863.32 & 24979.86 & 84751.99347 & & \\
\hline
\end{tabular}

Table 3. Student's $t$-test analysis of uS19 expression level between HCT116 and SW480

\begin{tabular}{lcccr}
\hline Cell lines & Mean (band intensity) & Standard deviation & $t$-value & $p$-value \\
\hline HCT116 & 118773.54 & 18532.23 & 6.314 & 0.026 \\
\hline
\end{tabular}




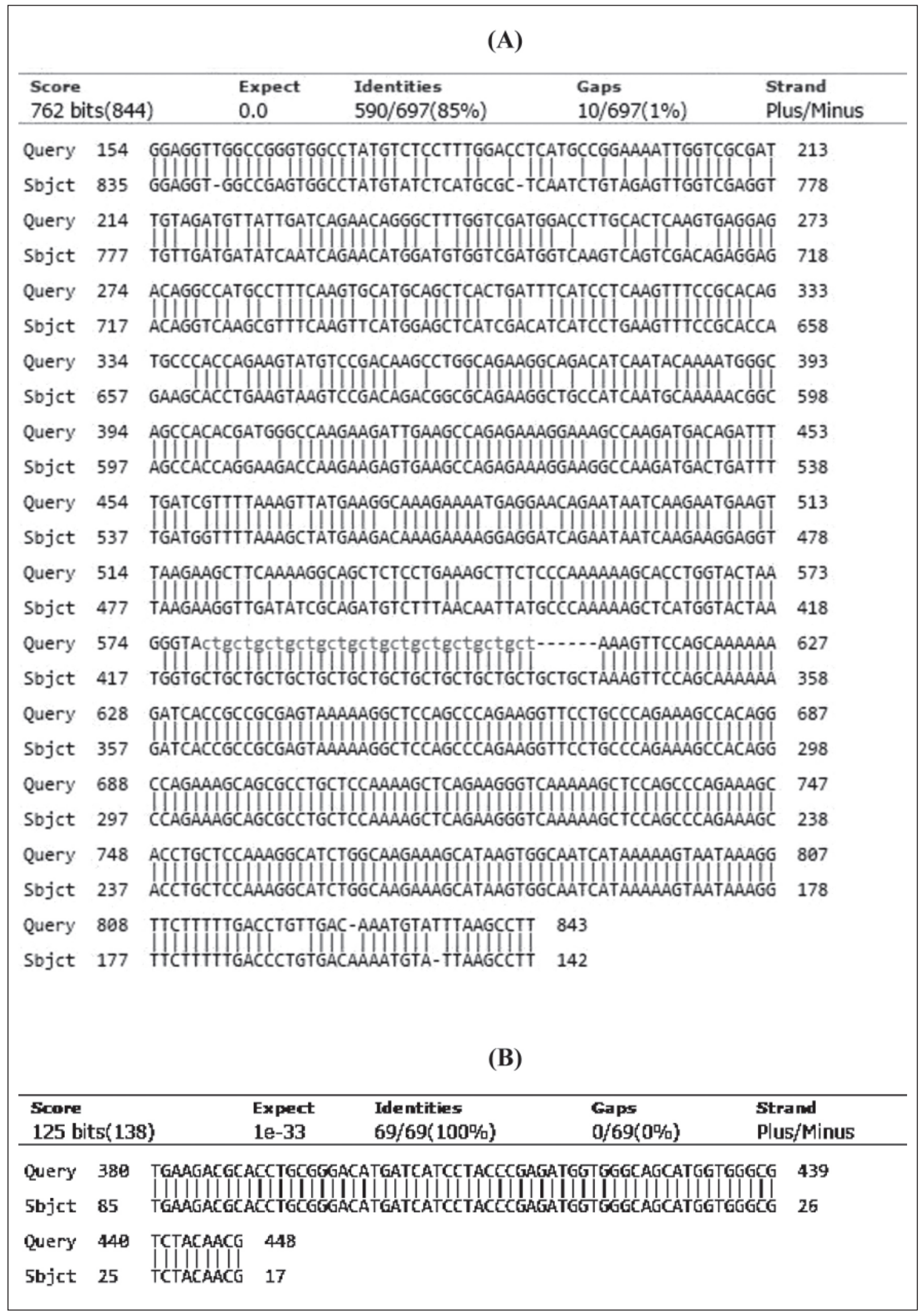

Fig. 3. Sequence verification via comparison of gene-of-interest sequence with reference data in GenBank: (A), eL14; (B), uS19; and (C), GAPDH. 
Figure 3 continued...

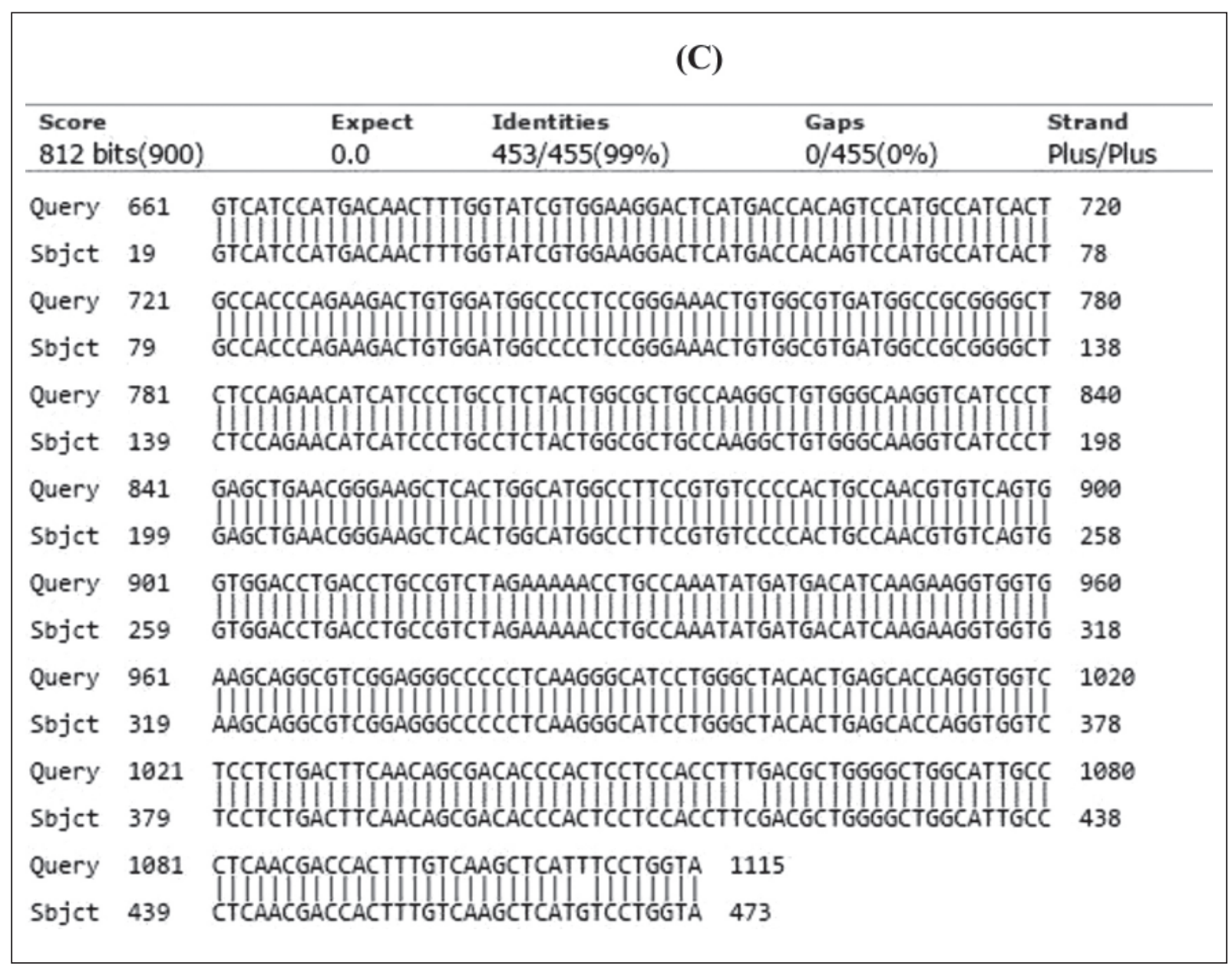

levels in the tested cell lines, including nonmalignant cell lines, is still required to verify our suspicion.

\section{CONCLUSION}

The RP genes of eL14 and $u S 19$ are highly expressed in the poorly differentiated metastatic cell line, HCT116 that originated from the ascending colon of colorectal carcinoma tissue. In the moderately differentiated epithelial-like (with glandular characteristics) non-metastatic cell line, SW480 that was derived from the descending colon of colorectal adenocarcinoma tissue, eL14 was not detected and uS19 was expressed but at a significantly lower level compared to HCT116. Both eL14 and $u S 19$ have potential as biomarkers to distinguish between different types and stages of colon cancer.

\section{ACKNOWLEDGEMENT}

This study is funded by the Ministry of Higher Education, Malaysia under the Fundamental Research Grant Scheme [grant code: FRGS/ ST03(01)/962/2013(03)].

\section{REFERENCES}

Ban, N., Beckmann, R., Cate, J.H., Dinman, J.D., Dragon, F., Ellis, S.R., Lafontaine, D.L., Lindahl, L., Liljas, A., Lipton, J.M. \& McAlear, M.A. 2014. A new system for naming ribosomal proteins. Current Opinions in Structural Biology, 24: 165-169. 
Bretones, G., Álvarez, M.G., Arango, J.R., Rodríguez, D., Nadeu, F., Prado, M.A., ValdesMas, R., Puente, D.A., Paulo, J.A., Delgado, J., Villamor, N., Lopez-Guillermo, A., Finley, D.J., Gygi, S.P., Campo, E., Quesada, V. \& LopezOtin, C. 2018. Altered patterns of global protein synthesis and translational fidelity in RPS15mutated chronic lymphocytic leukemia. Blood, The Journal of the American Society of Hematology, 132(22): 2375-2388.

Chomczynski, P. \& Sacchi, N. 1987. Single-step method of RNA isolation by acid guanidinium thiocyanate-phenol-chloroform extraction. Analytical Biochemistry, 162(1): 156-159.

Daftuar, L., Zhu, Y., Jacq, X. \& Prives, C. 2013. Ribosomal proteins RPL37, RPS15 and RPS20 regulate the Mdm2-p53-MdmX network. PLoS One, 8(7): e68667.

Fang, W., Li, X., Jiang, Q., Liu, Z., Yang, H., Wang, S., Xie, S., Liu, Q., Liu, T., Huang, J. \& Xie, W. 2008. Transcriptional patterns, biomarkers and pathways characterizing nasopharyngeal carcinoma of Southern China. Journal of Translational Medicine, 6(32): 1-13.

Flatmark, K., Mælandsmo, G.M., Martinsen, M., Rasmussen, H. \& Fodstad, Ø. 2004. Twelve colorectal cancer cell lines exhibit highly variable growth and metastatic capacities in an orthotopic model in nude mice. European Journal of Cancer, 40(10): 1593-1598.

Gou, Y., Shi, Y., Zhang, Y., Nie, Y., Wang, J., Song, J., Jin, H., He, L., Gao, L., Qiao, L. \& Wu, K. 2010. Ribosomal protein L6 promotes growth and cell cycle progression through upregulating cyclin E in gastric cancer cells. Biochemical and Biophysical Research Communications, 393: 788-793.

Huang, X.P., Zhao, C.X., Li, Q.J., Cai, Y., Liu, F.X., Hu, H., Xu, X., Han, Y.L., Wu, M., Zhan, Q.M. \& Wang, M.R. 2006. Alteration of RPL14 in squamous cell carcinomas and preneoplastic lesions of the esophagus. Gene, 366(1): 161-168.

Kawada, M., Mizuno, M., Nasu, J., Uesu, T., Okazaki, H., Okada, H., Shimomura, H., Yamamoto, K., Tsuji, T., Fujita, T. \& Shiratori, Y. 2003. Release of decay-accelerating factor into stools of patients with colorectal cancer by means of cleavage at the site of glycosylphosphatidylinositol anchor. Journal of Laboratory and Clinical Medicine, 142(5): 306-312.

Kondoh, N., Schweinfest, C.W., Henderson, K.W. \& Papas, T.S. 1992. Differential expression of S19 ribosomal protein, laminutesin-binding protein, and human lymphocyte antigen class I messenger RNAs associated with colon carcinoma progression and differentiation. Cancer Research, 52(4): 791-796.
Kreunin, P., Yoo, C., Urquidi, V., Lubman, D.M. \& Goodison, S. 2007. Differential expression of ribosomal proteins in a human model identified by coupling 2-D liquid chromatography and mass spectrometry. Cancer Genomics Proteomics, 4(5): 329-339.

Lai, M. \& Xu, J. 2007. Ribosomal proteins and colorectal cancer. Genomics, 8: 43-49.

Liu, X.Q., Chen, H.K., Zhang, X.S., Pan, Z.G., Li, A., Feng, Q.S., Long, Q.X., Wang, X.Z. \& Zeng, Y.X. 2003. Alterations of BLU, a candidate tumour suppressor gene on chromosome 3p21.3, in human nasopharyngeal carcinoma. International Journal of Cancer, 106(1): 60-65.

Ljungström, V., Cortese, D., Young, E., Pandzic, T., Mansouri, L., Plevova, K., Ntoufa, S., Baliakas, P., Clifford, R., Sutton, L.A. Blakemore, S.J., Stavroyianni, N., Agathangelidis, A., Rossi, D., Höglund, M., Kotaskova, J. Juliusson, G., Belessi, C., Chiorazzi, N., Panagiotidis, P., Langerak, A.W., Smedby, K.E., Oscier, D., Gaidano, G., Schuh, A., Davi, F., Pott, C., Strefford, J.C., Trentin, L., Pospisilova, S., Ghia, P., Stamatopoulos, K., Sjöblom, T. \& Rosenquist, R. 2016. Whole-exome sequencing in relapsing chronic lymphocytic leukemia: clinical impact of recurrent RPS15 mutations. Blood, The Journal of the American Society of Hematology, 127(8): 1007-1016.

Ljungström, V. \& Rosenquist, R. 2018. Not so lost in translation: RPS15 mutations in CLL. Blood, The Journal of the American Society of Hematology, 132(22): 2317-2319.

Mao, Q., Zhang, P.H., Yang, J., Xu, J.D., Kong, M., Shen, H., Zhu, H., Bai, M., Zhou, L., Li, G., Wang, Q. \& Li, S. 2016. iTRAQ-based proteomic analysis of Ginsenoside F2 on human gastric carcinoma cells SGC7901. Evidence-Based Complementary and Alternative Medicine, 2016: Article ID 2635483.

Niu, N., Zhang, J., Huang, T., Sun, Y., Chen, Z., Yi, W., Korteweg, C., Wang, J. \& Gu, J. 2012. IgG expression in human colorectal cancer and its relationship to cancer behaviors. PLoS One, 7(11): 247362.

Pogue-Geile, K., Geiser, J.R., Shu, M., Miller, C., Wool, I.G., Meisler, A.I. \& Pipas, J.M. 1991. Ribosomal protein genes are overexpressed in colorectal cancer: isolation of a cDNA clone encoding the human S3 ribosomal protein. Molecular and Cellular Biology, 11(8): 38423849.

Rajput, A., San Martin, I.D., Rose, R., Beko, A., LeVea, C., Sharratt, E., Mazurchuk, R., Hoffman, R.M., Brattain, M.G. \& Wang, J. 2008. Characterization of HCT116 human colon cancer cells in an orthotopic model. Journal of Surgical Research, 147: 276-281. 
Romano, P., Manniello, A., Aresu, O., Armento, M., Cesaro, B. \& Parodi, B. 2009. Cell lines database: Structure and recent improvements towards molecular authentication of human cell lines. Nucleic Acid Research, 37: D925-D932.

Shenoy, N., Kessel, R., Bhagat, T.D., Bhattacharyya, S., Yu, Y., Mcmahon, C. \& Verma, A. 2012. Alterations in the ribosomal machinery in cancer and hematologic disorders. Journal of Hematological Oncology, 5(1): 32.

Shriver, S.P., Shriver, M.D., Tirpak, D.L., Bloch, L.M., Hunt, J.D., Ferrell, R.E. \& Siegfried, J.M. 1998. Trinucleotide repeat length variation in the human ribosomal protein L14 gene (RPL14): localization to $3 \mathrm{p} 21.3$ and loss of heterozygosity in lung and oral cancers. Mutation Research/Mutation Research Genomics, 406(1): 9-23.

Sim, E.U.H., Chee, C.S.M., Vasudevan, L., Ng, K.L. \& Chan, S.L.L. 2018. Selective differential expression of the ribosomal protein genes eL14 and $u S 19$ in a well-differentiated epithelial cell line of nasopharyngeal carcinoma. Malaysian Applied Biology, 47(1): 247-253.

Sulima, S.O., Hofman, I.J., De Keersmaecker, K. \& Dinman, J.D. 2017. How ribosomes translate cancer. Cancer Discovery, 7(10): 1069-1087.

Walter, R.B., Obermoeller, R.D., Moore, D.D., Lacson, J.M., Della Coletta, L., McEntire, B.B., Morizot, D.C. \& Nairn, R.S. 1996. Characteristics and mapping of the Xiphophorus maculatus (Teleostei: Poeciliidae) RPS15 gene. Cytogenetics and Cell Genetics, 75: 140-144.
Wang, Y., Cheong, D., Chan, S. \& Hooi, S.C. 2000. Ribosomal protein $L 7 a$ gene is up-regulated but not fused to the tyrosine kinase receptor as chimeric trk oncogene in human colorectal carcinoma. International Journal of Oncology, 16(4): 757-819.

Yeung, T.M., Gandhi, S.C., Wilding, J.L., Muschel, R. \& Bodmer, W.F. 2010. Cancer stem cells from colorectal cancer-derived cell lines. Proceedings of the National Academy of Sciences, 107(8): 3722-3727.

Yoon, S.Y., Kim, J.M., Oh, J.H., Jeon, Y.J., Lee, D.S., Kim, J.H., Choi, J.Y., Ahn, B.M., Kim, S., Yoo, H.S. \& Kim, Y.S. 2006. Gene expression profiling of human $\mathrm{HBV}$ - and/or HCVassociated hepatocellular carcinoma cells using sequence tags. International Journal of Oncology, 29: 315-327.

Yu, C., Hong, H., Zhang, S., Zong, Y., Ma, J., Lu, A., Sun, J. \& Zheng, M. 2019. Identification of key genes and pathways involved in microsatellite instability in colorectal cancer. Molecular Medicine Reports, 19(3): 2065-2076. 
